\title{
PENGARUH METODE DEMONSTRASI TERHADAP KETERAMPILAN TEKNIK MENYUSUI PADA IBU POST SECTIO CAESAREA DI RSUD KOTA MATARAM TAHUN 2018
}

Tri Setya Mulyana $^{1}$, Irmayani ${ }^{2}$

1 Jurusan Kebidanan, Politeknik Kesehatan Kementrian Kesehatan Mataram

2. Jurusan Kebidanan, Politeknik Kesehatan Kementrian Kesehatan Mataram

\begin{abstract}
Abstrak
Latar Belakang : Menurut Profil Kesehatan NTB cakupan pemberian ASI eksklusif tahun 2016 yaitu $86,63 \%$, presentase ini sudah memenuhi target dalam pembangunan nasional dan strategi nasional sebesar $80 \%$. Meskipun NTB telah mencapai target nasional akan tetapi untuk wilayah Kota Mataram cakupan ASI eksklusif masih kurang dari target yakni sebesar 79,90\%. Informasi tentang teknik menyusui harus diberikan pada ibu post sectio caesarea karena pada ibu post sectio caesarea akan mengalami beberapa kendala seperti mobilisasi masih terbatas, tidak mengetahui teknik menyusui yang benar pada ibu post sectio caesarea, dan takut pada luka jahitan.

Tujuan : Mengetahui pengaruh metode demonstrasi terhadap keterampilan teknik menyusui pada ibu post sectio caesarea di RSUD Kota Mataram tahun 2018.

Metode : Penelitian ini menggunakan rancangan penelitian quasi eksperimen dengan pendektan nonequaivalent control group design dengan populasi seluruh ibu post sectio caesarea yang dirawat di RSUD Kota Mataram. Teknik pengambilan sampel yang digunakan adalah accidental sampling. Analisa data dengan menggunakan uji independent t test.

Hasil : Menunjukkan bahwa keterampilan teknik menyusui sebelum diberikan demonstrasi didapatkan rerata skor 56,9 sedangkan sesudah diberikan demonstrasi terjadi peningkatan yaitu rerata skor 84,6 dengan nilai $p$ value 0,000 .

Kesimpulan : Ada pengaruh metode demonstrasi terhadap keterampilan teknik menyusui pada ibu post sectio caesarea.
\end{abstract}

Kata Kunci : Demonstrasi, Keterampilan Teknik Menyusui, Ibu Post Sectio Caesarea

EFFECT OF DEMONSTRATION METHOD ON BREAST FEEDING TECHNIQUE TO MOTHER POST SECTIO CAESAREA AT MATARAM CITY HOSPITAL YEAR 2018

\begin{abstract}
Background : According to NTB's Health Profile the coverage of exclusive ASI in 2016 is $86.63 \%$, this percentage has met the target in national development and the national strategy is $80 \%$. Although NTB has reached the national target, but for Mataram City, the exclusive ASI coverage is still less than the target of $79.90 \%$. Information about breastfeeding techniques should be given to mothers post sectio caesarea because mothers post sectio caesarea will experience several problems such as limited mobilization, not knowing the correct breastfeeding technique for mothers post sectio caesarea, and fear of suture injuries.
\end{abstract}


Objective : To determine the effect of the demonstration method on breastfeeding technical skills in post sectio caesarean mothers in Mataram City Hospital 2018.

Methods : This study used astudy quasi experimental design with nonequaivalent control group design with a population of all mothers post sectio caesarea treated in Mataram City Hospital. The sampling technique used was accidental sampling. Data analysis using independent t test.

Result : Shows that breastfeeding technical skills before being given a demonstration obtained a mean score of 56.9 while after being given a demonstration there was an increase in the mean score of 84.6 with a $p$ value of 0.000 .

Conclusion : There is an effect of the demonstration method on breastfeeding technical skills on mothers post sectio caesarea.

Key words : Demonstration, Breastfeeding Technique Skills, Mother Post Sectio Caesarea

\section{Pendahuluan}

Menurut Global Breastfeeding Scorecard, yang mengevaluasi 194 negara, menemukan bahwa hanya 40\% anak-anak di bawah enam bulan yang disusui secara eksklusif (hanya diberi ASI ekslusif) dan hanya 23 negara yang memiliki tingkat menyusui eksklusif di atas $60 \%$ dengan target WHO sebesar 50\% bayi yang diberikan ASI ekslusif di seluruh dunia (WHO, 2017). ${ }^{1}$

Menurut data Riset Kesehatan Dasar tahun 2013 menunjukkan bahwa persentase pemberian ASI saja dalam 24 jam terakhir semakin menurun seiring meningkatnya umur bayi dengan persentase terendah pada anak umur 6 bulan (30,2\%), target ini masih jauh dari target nasional yaitu sebesar $80 \%$ (RISKESDAS, 2013). ${ }^{2}$

Cakupan pemberian ASI eksklusif di Provinsi NTB mengalami peningkatan pada tiga tahun berturut-turut yaitu sebanyak $68,81 \%$ tahun $2014,76,88 \%$ tahun 2015 dan meningkat menjadi 86,63\% pada tahun 2016. Tercatat cakupan pemberian ASI eksklusif di Provinsi NTB tahun 2016 yaitu Lombok Barat sebanyak 11.927 (94,81\%), Lombok Tengah 8.468 (90,86\%), Lombok Timur 21.553 (86,05\%), Sumbawa 4.032 (88,55\%), Dompu 18.350 (89,85\%), Bima 6.728 (77,40\%), Sumbawa Barat 2.293 (67,78\%), Lombok Utara 3.722 (85,21\%), Kota Mataram 3.713 (79,90\%) dan Kota Bima 1.245 (73,67\%) dengan target Provinsi NTB sebesar 80\% bayi diberikan ASI eksklusif. Ada beberapa kabupaten/kota di Provinsi NTB yang belum mencapai target yaitu Kab. Bima, Sumbawa Barat, Kota Bima, dan Kota Mataram (Profil Kesehatan NTB, 2016). ${ }^{3}$

Untuk meningkatkan pemahaman, pengetahuan dan keterampilan pada ibu harus diperoleh melalui praktik langsung tentang bagaimana teknik menyusui yang baik dan benar. Hal tersebut dapat disampaikan melalui pendidikan kesehatan berupa pengajaran, pelatihan, konseling, konsultasi dan media (Yoesvita, 2008). Informasi tentang teknik menyusui yang baik dan benar harus diberikan pada masa nifas terutama pada ibu post SC, karena pada ibu post SC dapat terjadi beberapa kendala seperti mobilisasi masih terbatas, tidak mengatahui cara teknik menyusui yang benar pada ibu post SC, dan takut pada luka jahitan. ${ }^{4}$

RSUD Kota Mataram merupakan salah satu Rumah Sakit dengan jumlah persalinan SC tertinggi yaitu 1.742 pada tahun 2017, dengan tingginya angka persalinan SC dilihat pada tahun 2017 diharapkan semua ibu bersalin SC dapat memberikan ASI kepada bayinya dengan cara dan 
teknik menyusui yang benar sehingga bayi bisa mendaptkan ASI eksklusif secara maksimal (Register RSUD Kota Mataram, 2017). ${ }^{5}$

Dari uraian di atas, maka peneliti tertarik untuk melakukan penelitian dengan judul "Pengaruh Metode Demonstrasi Terhadap Keterampilan Teknik Menyusui Pada Ibu Post Sectio Caesarea Di RSUD Kota Mataram Tahun 2018”.

\section{Metode}

Rancangan penelitian yang digunakan dalam penelitian ini adalah quasi experiment dengan pendekatan nonequaivalent control group design. Penelitian ini dibagi menjadi dua kelompok yaitu kelompok eksperimen dan kelompok kontrol. Kelompok eksperimen adalah kelompok yang mendapatkan demonstrasi, sedangkan kelompok kontrol diberikan media audio visual, akan tetapi sebelum diberikan intervensi peneliti telah melakukan pretest pada kedua kelompok untuk mengetahui perubahan yang terjadi setelah diberikan intervensi.

Populasi dalam penelitian ini adalah seluruh ibu post sectio caesarea yang dirawat di RSUD Kota Mataram.

Sampel pada penelitian ini adalah sebagian ibu post sectio caesarea yang dirawat di RSUD Kota Mataram selama dilakukan penelitian pada bulan Mei sampai bulan Juni 2018. Adapun teknik sampling yang digunakan yakni teknik Accidental Sampling.

Jadi sampel yang diambil dalam penelitian ini adalah sejumlah $30 \mathrm{ibu}$ post sectio caesarea yang dirawat di RSUD Kota Mataram pada saat penelitian berlangsung. Kemudian sampel dibagi menjadi dua kelompok yakni $15 \mathrm{ibu}$ post sectio caesarea sebagai kelompok intervensi dan $15 \mathrm{ibu}$ post sectio caesarea sebagai kelompok kontrol.

Variabel independen dalam penelitian ini adalah demonstrasi dan variabel dependen dalam penelitian ini adalah keterampilan teknik menyusui.

Hasil uji normalitas didapatkan keterampilan teknik menyusui pada ibu post sectio caesarea untuk variabel pretest ( $p$ value 0,161$)$ dan posttest ( $p$ value 0,140$)$ dengan hasil variabel berdistribusi normal yaitu $p$ value $>0,05$ sehingga menggunakan metode statistik parametrik, dan untuk menguji analisis bivariat menggunakan uji analisis independent $t$ test untuk mengetahui apakah ada pengaruh metode demonstrasi terhadap keterampilan teknik menyusui pada ibu post sectio caesarea.

\section{Hasil}

Tabel 1. Keterampilan teknik menyusui pada ibu post sectio caesarea sebelum dan sesudah diberikan demonstrasi

\begin{tabular}{|l|l|l|l|l|l|}
\hline Keterampilan & $\mathbf{n}$ & Mean & SD & Min & Max \\
\hline Sebelum & \multirow{2}{*}{15} & 56,9 & 3,34 & 52,0 & 63,0 \\
\cline { 3 - 6 } & \multirow{2}{*}{ Sesudah } & 84,6 & 3,79 & 77,0 & 90,0 \\
\hline
\end{tabular}

Berdasarkan Tabel 1. Menunjukan bahwa sebelum diberikan demonstrasi didapatkan hasil rerata skor keterampilan teknik menyusui pada ibu post sectio caesarea adalah 56,9 dengan standar 
deviasi 3,34, nilai keterampilan terendah adalah 52,0 dan nilai tertinggi 63,0. Sedangkan sesudah diberikan demonstrasi didapatkan hasil rerata skor keterampilan teknik menyusui pada ibu post sectio caesarea adalah 84,6 dengan standar deviasi 3,79, nilai keterampilan terendah adalah 77,0 dan nilai tertinggi 90,0 .

Tabel 2. Keterampilan teknik menyusui pada ibu post sectio caesarea sebelum dan sesudah diberikan media audio visual

\begin{tabular}{|l|l|l|l|l|l|}
\hline Keterampilan & n & Mean & SD & Min & Max \\
\hline Sebelum & \multirow{3}{*}{15} & 57,0 & 2,75 & 52,0 & 63,0 \\
\cline { 1 - 5 } & & 70,8 & 4,86 & 63,0 & 79,0 \\
\hline Sesudah & & &
\end{tabular}

Berdasarkan Tabel 2. Menunjukkan bahwa sebelum diberikan media audio visual didapatkan hasil rerata skor keterampilan teknik menyusui pada ibu post sectio caesarea adalah 57,0 dengan standar deviasi 2,75, nilai keterampilan terendah adalah 52,0 dan nilai tertinggi 63,0. Sedangkan sesudah diberikan media audio visual didapatkan hasil rerata skor keterampilan teknik menyusui pada ibu post sectio caesarea adalah 70,8 dengan standar deviasi 4,86 , nilai keterampilan terendah adalah 63,0 dan nilai tertinggi 79,0.

Tabel 3. Analisis pengaruh metode demonstrasi terhadap keterampilan teknik menyusui pada ibu post sectio caesarea di RSUD Kota Mataram tahun 2018

\begin{tabular}{|l|l|l|l|l|l|}
\hline Kelompok & $\mathbf{n}$ & Mean & SD & SE & $\begin{array}{l}\text { P } \\
\text { value }\end{array}$ \\
\hline Intervensi & 15 & 84,6 & 3,79 & 0,79 & \multirow{2}{*}{0,00} \\
\hline Kontrol & 15 & 70,8 & 4,86 & 1,25 & \\
\hline
\end{tabular}

Berdasarkan Tabel 3. Menunjukkan bahwa hasil uji independent t test diperoleh nilai $p$ value yaitu $0,000<0,05$ maka $\mathrm{H}_{0}$ ditolak dan $\mathrm{H}_{\mathrm{a}}$ diterima, maka dapat disimpulkan bahwa terdapat perbedaan keterampilan yang signifikan antara kelompok intervensi dan kelompok kontrol sehingga dapat disimpulkan bahwa ada pengaruh metode demonstrasi terhadap keterampilan teknik menyusui pada ibu post sectio caesarea di RSUD Kota Mataram tahun 2018.

\section{Diskusi}

A. Keterampilan teknik menyusui sebelum dan sesudah diberikan demonstrasi pada ibu post sectio caesarea

1. Keterampilan teknik menyusui sebelum diberikan demonstrasi

Hasil penelitian menunjukkan bahwa pada kelompok intervensi sebelum diberikan penyuluhan dengan menggunakan metode demonstrasi didapatkan rerata skor keterampilan teknik menyusui adalah 56,9 dengan standar deviasi 3,34, nilai keterampilan terendah yaitu 52,0 dan nilai tertinggi 63,0 . 
Berdasarkan hasil dari penilaian menggunakan ceklist dengan jumlah poin 16 langkah teknik menyusui yang benar didapatkan hasil $0 \%$ ibu tidak mengoleskan ASI sedikit pada putting susu dan areola, 20\% perut bayi tidak menempel pada perut ibu, 20\% leher dan badan bayi tidak dalam satu garis lurus, $0 \%$ lengan bayi tidak diletakkan dibelakang badan ibu, 33\% payudara tidak dipegang dengan ibu jari diatas dan jari yang lain menopang dibawah, 40\% sebagian areola tidak masuk ke mulut bayi dan 17\% dagu bayi tidak menempel pada payudara ibu.

Skinner seorang ahli psikologi merumuskan bahwa perilaku merupakan respons atau reaksi seseorang terhadap stimulus (rangsangan dari luar). Oleh karena itu perilaku terjadi melalui proses adanya stimulus terhadap organisme dan kemudian organisme tersebut merespon, yang mana teori skinner ini disebut dengan teori "S-O-R". 6

Hasil penelitian ini sejalan dengan penelitian Laily Himawati yaitu pengaruh pendidikan kesehatan tentang teknik menyusui terhadap pengetahuan dan perilaku teknik menyusui pada ibu primipara di BPS Kecamatan Kalibang Kulonprogo Tahun 2011. Berdasakan hasil penelitian rerata perilaku responden sebelum diberikan pendidikan kesehatan adalah 10,76. ${ }^{7}$

Hasil penelitian ini di dukung oleh penelitian Felsa Anggita tentang pengaruh pemberian penyuluhan tentang cara menyusui terhadap perilaku menyusui bayi di desa Panggung Rejo, kecamatan Jebres, kota Surakarta tahun 2012. Hasil penelitian sebelum diberikan penyuluhan perilaku responden yang mempunyai kategori di atas rata-rata sebanyak 24 ibu menyusui $(59 \%)^{8}$

Informasi tentang teknik menyusui yang baik dan benar harus diberikan pada masa nifas terutama pada ibu post sectio caesarea, karena pada ibu post sectio caesarea dapat terjadi beberapa kendala seperti mobilisasi masih terbatas, tidak mengatahui cara teknik menyusui yang benar pada ibu post sectio caesarea, dan takut pada luka jahitan. Penelitian ini sesuai dengan penelitian Kumar, dkk (2014) yang menyatakan bahwa inisiasi pemberian ASI lebih rendah pada ibu yang melahirkan dengan sectio caesarea dibanding ibu yang melahirkan pervaginam. Ibu post sectio caesarea berisiko tiga kali lebih besar untuk terlambat melakukan inisiasi menyusui dibanding dengan melahirkan pervaginam dan pemberian ASI eksklusif pada ibu melahirkan dengan sectio caesarea kepada bayinya juga didapatkan 16\% lebih rendah dibandingkan dengan ibu melahirkan pervaginam (Wulandari, 2014). ${ }^{9}$

\section{Keterampilan teknik menyusui sesudah diberikan demonstrasi}

Hasil penelitian menunjukkan bahwa pada kelompok intervensi sesudah diberikan penyuluhan menggunakan metode demonstrasi mengalami peningkatan dengan rerata skor keterampilan teknik menyusui adalah 84,6, standar deviasi 3,79, nilai keterampilan terendah yaitu 77,0 dan nilai tertinggi 90,0.

Berdasarkan hasil penilaian sesudah diberikan demonstrasi dengan menggunakan ceklist dengan jumlah poin 16 langkah teknik menyusui yang benar didapatkan hasil 0\% lengan bayi tidak diletakkan dibelakang badan ibu, 66\% ibu mengoleskan ASI sedikit pada putting susu dan areola, 77\% perut bayi menempel pada perut ibu, 64\% leher dan badan bayi dalam satu garis lurus, $73 \%$ payudara dipegang dengan ibu jari diatas dan jari yang lain menopang 
dibawah, 100\% sebagian areola masuk ke mulut bayi dan $73 \%$ dagu bayi menempel pada payudara ibu.

Nilai rerata skor keterampilan teknik menyusui sesudah diberikan demonstrasi mengalami peningkatan hal tersebut karena metode demonstrasi melibatkan lebih banyak indra seperti indra penglihatan, indra pendengaran dan indra peraba. Seseorang akan lebih cepat dan mengerti dalam menerima hal baru dari apa yang mereka lihat, dengar, dan melakukannya sendiri. Hal ini sesuai dengan teori Edgar Dale mengenai efektifitas alat peraga dalam meningkatkan pengetahuan dan keterampilan seseorang. Edgar Dale menggambarkan intensitas alat peraga tersebut dalam sebuah kerucut yang dikenal dengan kerucut Edgar Dale. Menurut kerucut tersebut, pemberian pendidikan kesehatan dengan metode demonstrasi akan lebih efektif dalam menyampaikan tujuan dari pendidikan kesehatan tersebut dengan keefektifan sebesar $50 \%{ }^{10}$

Hasil penelitian ini sejalan dengan penelitian Laily Himawati, dari hasil penelitian rerata skor perilaku responden sesudah diberikan pendidikan kesehatan adalah 15,00. Hal ini menggambarkan adanya peningkatan perubahan perilaku menyusui ibu primipara tentang teknik menyusui setelah diberikan pendidikan kesehatan.

Hasil penelitian ini di dukung oleh penelitian Felsa Anggita tentang pengaruh pemberian penyuluhan tentang cara menyusui terhadap perilaku menyusui bayi di desa Panggung Rejo, kecamatan Jebres, kota Surakarta tahun 2012. Hasil penelitian sesudah diberikan penyuluhan perilaku responden yang mempunyai kategori di atas rata-rata sebanyak 26 ibu menyusui $(63 \%)$.

B. Keterampilan teknik menyusui sebelum dan sesudah diberikan media audio visual pada ibu post sectio caesarea

\section{Keterampilan teknik menyusui sebelum diberikan media audio visual}

Hasil penelitian menunjukkan bahwa pada kelompok kontrol sebelum diberikan penyuluhan dengan menggunakan media audio visual didapatkan rerata skor keterampilan teknik menyusui adalah 57,0 dengan standar deviasi 2,75 , nilai keterampilan terendah yaitu 52,0 dan nilai tertinggi 63,0.

Berdasarkan hasil penilaian sebelum diberikan media audio visual dengan menggunakan ceklist dengan jumlah poin 16 langkah teknik menyusui yang benar didapatkan hasil 0\% ibu tidak mengoleskan ASI sedikit pada putting susu dan areola, 11\% perut bayi tidak menempel pada perut ibu, 11\% leher dan badan bayi tidak dalam satu garis lurus, $0 \%$ satu lengan bayi tidak diletakkan dibelakang badan ibu, 33\% payudara tidak dipegang dengan ibu jari diatas dan jari yang lain menopang dibawah, dan $8,8 \%$ dagu bayi tidak menempel pada payudara ibu.

Keterampilan tentang teknik menyusui adalah pemahaman responden tentang teknik menyusui yang diperoleh dari sumber informasi ataupun pengalaman yang didapatkan di lingkungan. Ketika responden mendapati orang di sekitar mereka menyusui, maka prilaku yang diperoleh dari situasi tersebut menjadi sumber informasi bagi ibu tentang teknik menyusui yang benar. Hal ini sesuai dengan penelitian Suliha (2002) tentang hubungan informasi dan 
pengalaman terhadap pengetahuan yang mengemukakan bahwa salah satu faktor yang mempengaruhi pengetahuan adalah pengalaman. ${ }^{11}$

Penelitian lain oleh Gapmelezzy dan Ekowati (2009) menyebutkan bahwa teknik menyusui yang benar ditentukan oleh pengetahuan ibu yang baik. Pengetahuan yang baik tentang pentingnya ASI dan cara menyusui akan membentuk sikap yang positif, selanjutnya akan terjadi prilaku menyusui yang benar. ${ }^{12}$

\section{Keterampilan teknik menyusui sesudah diberikan media audio visual}

Hasil penelitian menunjukkan bahwa pada kelompok kontrol sesudah diberikan penyuluhan dengan menggunakan media audio visual didapatkan rerata skor keterampilan teknik menyusui adalah 70,8 dengan standar deviasi 4,86, nilai keterampilan terendah yaitu 63,0 dan nilai tertinggi 79,0.

Berdasarkan hasil penilaian sesudah diberikan media audio visual dengan menggunakan ceklist dengan jumlah poin 16 langkah teknik menyusui yang benar didapatkan hasil 0\% lengan bayi tidak diletakkan dibelakang badan ibu, 33\% ibu mengoleskan ASI sedikit pada putting susu dan areola, 24\% perut bayi menempel pada perut ibu, 24\% leher dan badan bayi dalam satu garis lurus, $60 \%$ payudara dipegang dengan ibu jari diatas dan jari yang lain menopang dibawah, $100 \%$ sebagian areola masuk ke mulut bayi dan $20 \%$ dagu bayi menempel pada payudara ibu.

Nilai rerata skor keterampilan teknik menyusui sesudah diberikan media audio visual mengalami peningkatan hal tersebut sesuai dengan teori Daryanto (2011) yang menyatakan bahwa video sebagai media pendidikan kesehatan dapat memperkokoh proses belajar maupun nilai hiburan dari penyajian. ${ }^{13}$

Hasil penelitian ini didukung oleh penelitian Saputra (2011) yang menyatakan bahwa sebanyak 15 dari 16 responden yang diberikan pendidikan kesehatan dengan media audio visual mengalami peningkatan pengetahuan $(p$ value $=0,000)$ dengan nilai efektifitas sebesar $93,75 \% .^{14}$

\section{Pengaruh metode demonstrasi terhadap keterampilan teknik menyusui pada ibu post sectio caesarea}

Dari hasil analisis yang dilakukan dengan uji independent $t$ test diperoleh hasil penelitian yaitu nilai $p$ value $=0,000<\alpha=0,05$, maka $\mathrm{H}_{0}$ ditolak dan $\mathrm{H}_{\mathrm{a}}$ diterima. Hal ini menunjukkan bahwa ada pengaruh yang signifikan antara kelompok intervensi dan kelompok kontrol sehingga dapat disimpulkan bahwa ada pengaruh metode demonstrasi terhadap keterampilan teknik menyusui pada ibu post sectio caesarea di RSUD Kota Mataram.

Pengaruh metode demonstrasi terhadap keterampilan teknik menyusui pada ibu post sectio caesarea terdapat peningkatan keterampilan sesudah diberikan demonstrasi. Hal tersebut mengindikasikan bahwa penerapan saat memberikan informasi dengan menggunakan metode demonstrasi jika mengalami kesulitan bisa terselesaikan dengan adanya tanya jawab antara responden dan konselor. Hal ini juga disebabkan oleh metode demonstrasi lebih efektif dibandingkan dengan media audio visual yang dapat dilihat dari nilai rerata skor sesudah 
diberikan pendidikan kesehatan, tiap individu yang mendapatkan demonstrasi dianggap lebih menarik dan memicu ibu untuk mempraktikkan langsung kepada bayinya.

Berdasarkan hasil penelitian yang telah dilakukan, diketahui bahwa dengan adanya intervensi berupa demonstrasi ternyata dapat mempengaruhi keterampilan teknik menyusui pada ibu post sectio caesarea. Sehingga dengan adanya pengaruh tersebut dapat terjadi perubahan perilaku pada ibu post sectio caesarea untuk melakukan teknik menyusui dengan cara yang benar pada bayinya. Diperoleh dari hasil penelitian pre dan post test menggunakan ceklist pada ibu post sectio caesarea yaitu sebelum diberikan demonstrasi didapatkan hasil rerata skor keterampilan teknik menyusui 56,9 dengan nilai terendah 52,0 dan nilai tertinggi 63,0 . Sedangkan sesudah diberikan demonstrasi didapatkan hasil rerata skor keterampilan teknik menyusui adalah 84,6 dengan nilai terendah 77,0 dan nilai tertinggi yaitu 90,0.

Didukung dengan pernyataan Mubarak (2007) yang menyatakan bahwa pemberian pendidikan kesehatan mampu mengubah tingkat pengetahuan menjadi lebih baik sehingga berperilaku sesuai dengan yang diharapkan. Namun dalam proses pendidikan kesehatan agar diperoleh hasil yang lebih efektif diperlukan peragaan dan metode pendidikan kesehatan yang efektif. Demonstrasi merupakan metode yang efektif untuk menanamkan pengetahuan, motivasi, keterampilan dan kemampuan (Notoatmodjo, 2012). ${ }^{15}$

Penelitian ini didukung oleh penelitian Nanda Wilda (2016) dari hasil penelitian didapatkan rata-rata kemampuan ibu menyusui sebelum dilakukan demonstrasi dan pendampingan menyusui adalah 11,9 dengan skor maksimal 15 dan skor minimal 9. Rata-rata kemampuan ibu menyusui sesudah dilakukan demonstrasi dan pendampingan menyusui adalah 17,05 dengan skor maksimal 21 dan skor minimal 13. Ada pengaruh demonstrasi dan pendampingan menyusui terhadap kemampuan ibu dalam menyusui di Ruang Kebidanan RSUD dr. Rasidin Padang. ${ }^{16}$

Hasil penelitian didapatkan rerata skor keterampilan teknik menyusi sebelum diberikan demonstrasi adalah 56,9 dan sesudah pemberian demonstrasi didapatkan rata-rata keterampilan teknik menyusui adalah 84,6 . Sedangkan rerata skor keterampilan teknik menyusi pada kelompok kontrol sebelum diberikan media audio visual adalah 57,0 sesudah diberikan media audio visual didapatkan rerata skor keterampilan teknik menyusui adalah 70,8. Dari hasil analisis diatas terlihat jelas selisih rerata skor keterampilan teknik menyusui sesudah pemberian demonstrasi pada kelompok intervensi serta pemberian media audio visual pada kelompok kontrol. Hasil tersebut membuktikan bahwa pemberian pendidikan kesehatan dengan metode demonstrasi lebih efektif atau lebih berpengaruh terhadap keterampilan teknik menyusui dibandingkan dengan media audio visual. Uji statistik dengan menggunakan uji independent $t$ test yang telah dilakukan terdapat nilai $p$ value adalah 0,000 , dengan demikian nilai $p$ value lebih kecil dari nilai $(0,05)$ atau $p$ value $0,000<0,05$. Maka dapat disimpulkan $\mathrm{H}_{0}$ ditolak dan $\mathrm{H}_{\mathrm{a}}$ diterima dengan artian terdapat perbedaan yang signifikan antara rerata skor keterampilan teknik menyusui sesudah pemberian demonstrasi. Berdasarkan hasil tersebut dapat disimpulkan bahwa berhasilnya metode demonstrasi terhadap keterampilan teknik menyusui pada ibu post sectio caesarea. 


\section{Kesimpulan}

Ada pengaruh metode demonstrasi terhadap keterampilan teknik menyusui pada ibu post sectio caesarea dengan diperoleh hasil penelitian nilai $p$ value $=0,000$.

\section{Ucapan Terima Kasih}

Ucapan terimakasih penulis sampaikan kepada ibu-ibu yang menjadi responden penelitian ini dan semua pihak yang telah membantu sehingga penelitian ini bisa selesai tepat pada waktunya serta terlaksana sesuai dengan yang direncanakan.

\section{Daftar Pustaka}

1. World Health Organization (WHO). Global Breastfeeding Scorecard 2017. UNICEF

2. Badan Penelitian dan Pengembangan Kesehatan Kementrian RI. 2013. Riset Kesehatan Dasar Tahun 2013. Jakarta

3. Dinas Kesehatan Provinsi NTB. 2016. Profil Kesehatan Provinsi NTB 2016. NTB : Dikes Provinsi NTB

4. Yoesvita, E. (2008). Promosi Kesehatan dengan Konseling dan Penyuluhan ASI Eksklusif pada Ibu Menyusui di Kecamatan Darul Imarah Kabupaten Aceh Besar Propinsi Naggroe Aceh Darussalam Tahun 2007. Yogyakarta: Unpublished Thesis UGM.

5. Register RSUD Kota Mataram. 2017. Register RSUD Kota Mataram Tahun 2017. RSUD Kota Mataram

6. Skinner. 2014. Promosi Kesehatan dan Perilaku Kesehatan. Jakarta : Ed. Rev - Rineka Cipta

7. Laily, Himawati. 2011. Pengaruh Pendidikan Kesehatan Tentang Teknik Menyusui Terhadap Pengetahuan Dan Perilaku Teknik Menyusui Pada Ibu Primipara Di BPS Kecamatan Kalibang Kulonprogo Tahun 2011. Skripsi Mahasiswa D-IV Bidan Pendidik STIKES Aisyiyah Yogyakarta

8. Felsa Anggita, N. 2012. Pengaruh Pemberian Penyuluhan Tentang Cara Menyusui Terhadap Perilaku Menyusui Bayi. KTI Mahasiswa D-IV Bidan Pendidik Fakultas Kedokteran Universitas Sebelas Maret. Surakarta

9. Wulandari R., dkk. 2014. Rendahnya Praktik Menyusui pada Ibu Post Sectio Caesarea dan Dukungan Tenaga Kesehatan di Rumah Sakit. Penelitian Departemen Ilmu Kesehatan Masyarakat Kedokteran Pencegahan Fakultas Kedokteran Universitas Airlangga

10. Dale, Edgar. 1969. Audio Visual Methods in Teaching. New York: Holt, Rinehart and Winston Inc. The Dryden Press. 
11. Suliha. 2002. Pendidikan Kesehatan dalam Keperawatan. Jakarta : EGC

12. Gapmelezzy, dkk. 2009. Pengetahuan Ibu Tentang ASI Hubungannya Dengan Pemberian ASI Eksklusif di Puskesmas Wonosari Kecamatan Wonosari Kabupaten Gunung Kidul. Karya Tulis Ilmiah. Universitas Gajah Mada. Yogyakarta

13. Daryanto. 2011. Media Pembelajaran. Bandung : Satu Nusa. p: 5,13,79-81

14. Saputra, N. 2011. Perbedaan Pengaruh Pendidikan Kesehatan HIV AIDS Dengan Metode Curah Pendapat Dan Ceramah Menggunakan Media Audiovisual Terhadap Pengetahuan Siswi SMAN 4 Tanggerang Selatan. Tugas Akhir Universitas Islam Negeri Syarif Hidayatullah. Jakarta

15. Mubarak, W.l, Chayatin N, Rozikin, Khoirul, Supardi.(2007). Promosi Kesehatan SebuahPengantar Belajar Mengajar Dalam Pendidikan.yogyakarta:Graha Ilmu

16. Nanda Wilda, L. 2016. Pengaruh Demonstrasi Dan Pendampingan Menyusui Terhadap Kemampuan Ibu Dalam Menyusui Di Ruang Kebidanan RSUD dr. Rasidin Padang. Skripsi Mahasiswa Program Studi S1 Keperawatan Fakultas Keperawatan Universitas Andalas 